\title{
PERTUMBUHAN TANAMAN PAKCOY SETELAH PEMBERIAN PUPUK URIN KELINCI
}

\author{
Rosdiana \\ e-mail: hani.putri33@yahoo.com \\ Fakultas Pertanian Universitas Muhammadiyah Jakarta
}

\begin{abstract}
This article discusses the growth and yield response pakcoy (Brassica rapa) wick hydroponic system with several doses of organic fertilizer rabbit urine. The experiment was conducted for three months starting in May until July 2014. The experimental design used in this research is the design group Complete randomized (RKLT) which consists of five treatment dose of rabbit urine liquid organic fertilizer, which is $3 \mathrm{~m} / /, 6 \mathrm{~m} / / /, 9 \mathrm{~m} / /, 12 \mathrm{~m} / /, 15 \mathrm{~m} / / /$. Each treatment consisted of four plants and is repeated five times, so the total number of tests on a piece of land is as much as 100 plants. Observations were made at the variable plant height, leaf length, leaf width, number of leaves, fresh weight and the weight of consumption. Various doses of liquid organic fertilizer rabbit urine does not provide any real effect on the parameters of the plant height, number of leaves, leaf length, leaf width, wet weight and the weight of consumption. Dosage of liquid organic fertilizer rabbit urine 12 $\mathrm{m} / \mathrm{l}$ give the highest yield for plant height, number of leaves, leaf length, leaf width, wet weight and the weight of consumption. Dose of liquid organic fertilizer rabbit urine $3 \mathrm{~m} / / \mathrm{l}$ giving the lowest result in all variables.
\end{abstract}

Keywords: fertilizer rabbit urine, pakcoy plants, wick system hydroponic.

\begin{abstract}
ABSTRAK
Artikel ini membahas respon pertumbuhan dan produksi tanaman pakcoy (Brassica rapa) secara hidroponik sistem wick dengan pemberian berbagai dosis pupuk organik urin kelinci. Penelitian dilaksanakan selama tiga bulan dimulai pada bulan Mei sampai Juli 2014. Rancangan percobaan yang digunakan dalam penelitian ini adalah Rancangan Kelompok Lengkap Teracak (RKLT) yang terdiri atas lima perlakuan dosis pupuk organik cair urin kelinci, yaitu $3 \mathrm{ml} / /, 6 \mathrm{ml} / /, 9 \mathrm{ml} / \mathrm{l}, 12 \mathrm{ml} / /, 15$ $\mathrm{ml} /$. Tiap perlakuan terdiri atas empat tanaman dan diulang sebanyak lima kali, sehingga jumlah total ujicoba pada suatu lahan adalah sebanyak 100 tanaman. Pengamatan dilakukan pada peubah tinggi tanaman, panjang daun, lebar daun, jumlah daun, bobot basah, dan bobot konsumsi. Berbagai dosis pupuk organik cair urin kelinci tidak memberikan pengaruh yang nyata pada terhadap parameter tinggi tanaman, jumlah daun, panjang daun, lebar daun, bobot basah dan bobot konsumsi. Perlakuan dosis pupuk organik cair urin kelinci $12 \mathrm{~m} / /$ memberikan hasil tertinggi untuk tinggi tanaman, jumlah daun, panjang daun, lebar daun, bobot basah, dan bobot konsumsi. Dosis pupuk organik cair urin kelinci $3 \mathrm{ml} / \mathrm{l}$ memberikan hasil yang terrendah pada semua peubah.
\end{abstract}

Kata kunci: hidroponik sistem wick, pupuk urin kelinci, tanaman pakcoy.

Keadaan alam Indonesia memungkinkan dilakukannya pembudidayaan berbagai jenis tanaman sayuran, baik yang lokal maupun yang berasal dari luar negeri. Hal tersebut menyebabkan Indonesia ditinjau dari aspek klimatologis sangat potensial dalam usaha bisnis sayur-sayuran. Tanaman pakcoy merupakan salah satu jenis sayuran yang banyak dikonsumsi oleh masyarakat, 
karena jenis sayuran ini memiliki prospek yang baik untuk dikembangkan karena mempunyai kandungan gizi yang cukup tinggi (Haryanto, Suhartini, Rahayu \& Sunarjo, 2007).

Menurut Zulkarnain (2010), pakcoy dapat dikategorikan kedalam sayuran daun berdasarkan bagian yang dikonsumsi. Setiap $100 \mathrm{~g}$ tanaman pakcoy mengandung mineral, vitamin A $3600 \mathrm{SI}$, vitamin B1 0,1 mg, vitamin B2 0,1 mg dan vitamin C 74 mg, protein1,8 g dan kalori 21 kal. Saat ini pakcoy dengan mudah diperoleh dipasaran sehingga dapat dipastikan permintaan pasarnya cukup tinggi, namun kualitas dan kuantitas yang ada di pasar saat ini masih beragam.

Teknik budidaya yang kurang baik akan mengurangi hasil produksi tanaman pakcoy. Upaya untuk menanggulangi kendala tersebut adalah dengan memperbaiki teknik budidaya tanaman pakcoy. Salah satu cara yang diharapkan mampu mendukung pertumbuhan dan meningkatkan produktivitas tanaman pakcoy adalah dengan sistem hidroponik. Hidroponik merupakan teknik bertanam tanpa menggunakan media tanah. Teknik ini mampu meningkatkan hasil tanaman per satuan luas sampai lebih dari sepuluh kali, bila dibandingkan dengan teknik pertanian konvensional (Basuki, 2008).

Pada dasarnya ada enam jenis sistem hidroponik yaitu sistem wick, budaya air, EBB dan aliran, tetes, film teknik hara, dan aeroponik. Di antara berbagai jenis sistem hidroponik, cara bertanam hidroponik sistem wick adalah jenis yang paling sederhana. Cara bertanam hidroponik sistem wick merupakan sebuah solusi pemberian nutrisi melalui sumbu ke media tanam yang digunakan sebagai reservoir. Sistem ini dapat menggunakan berbagai media tanam, misalnya perlite, vermiculite, kerikil pasir, sekam bakar, dan cocopeat. Cara bertanam hidroponik ini juga dikenal dengan sistem sumbu (Afrizal, 2012).

Hal yang perlu diperhatikan dalam pengembangan teknologi hidroponik adalah pemberian nutrisi atau pemupukan. Pupuk organik cair dapat dijadikan sebagai salah satu alternatif sumber larutan nutrisi. Selain praktis, pupuk organik cair juga mudah diperoleh di pasaran. Urin kelinci adalah salah satu pupuk organik cair yang memiliki kandungan nitrogen $(\mathrm{N})$ yang melimpah dimana kandungan tersebut penting bagi tanaman. Unsur $\mathrm{N}$ diperlukan oleh tanaman untuk pembentukan bagian vegetatif tanaman, seperti daun, batang, dan akar serta berperan vital pada saat tanaman melakukan fotosintesa, sebagai pembentuk klorofil (Anonim, 2010).

Menurut Paiman dan Erika (2010), hasil penelitian pada tanaman tomat menunjukan bahwa konsentrasi urin kelinci memberikan pengaruh nyata terhadap berat segar tanaman, berat kering tanaman, berat kering daun, berat kering batang, dan berat kering akar. Penelitian Mappanganro, Sengin, dan Baharuddin (2012) urin kelinci $6 \mathrm{ml} / \mathrm{l}$ menunjukkan hasil terbaik pada umur berbunga stroberi, umur berbuah, jumlah bunga, jumlah buah, panjang buah, diameter buah, berat buah, dan produksi per tanaman stroberi dengan sistem hidroponik tetes.

Penelitian ini bertujuan mengukur respon pertumbuhan dan produksi tanaman pakcoy secara hidroponik sistem wick setelah pemberian berbagai dosis pupuk organik cair urin kelinci serta menentukan dosis yang paling baik untuk pertumbuhan dan produksi tanaman pakcoy secara hidroponik sistem wick.

\section{METODE}

Penelitian dilaksanakan selama tiga bulan dimulai pada bulan Mei sampai Juli 2014 di Kebun Percobaan Fakultas Pertanian Universitas Muhammadiyah Jakarta yang berada pada ketinggian \pm 25 meter di atas permukaan laut (dpl). Bahan yang digunakan dalam penelitian ini adalah bibit pakcoy, sekam bakar, pupuk organik cair urin kelinci, label, kain fanel, pestisida dan air. Sedangkan alat yang digunakan adalah botol mineral 1,5 liter, ember, alat ukur, alat tulis, alat pembolong dan 
kamera. Penelitian ini menggunakan Rancangan Kelompok Lengkap Teracak (RKLT) yang terdiri dari lima perlakuan dosis pupuk organik cair urin kelinci, yaitu P1 $=3 \mathrm{ml} / /, \mathrm{P} 2=6 \mathrm{ml} / \mathrm{l}, \mathrm{P} 3=9 \mathrm{ml} / \mathrm{l}, \mathrm{P} 4$ $=12 \mathrm{ml} / \mathrm{l}$ dan P5 = $15 \mathrm{ml} / \mathrm{l}$.

Tiap perlakuan terdiri dari 4 tanaman dan diulang sebanyak 5 kali, sehingga terdapat populasi pada suatu lahan sebanyak 100 tanaman percobaan. Data hasil pengukuran dianalisis secara statistik dengan menggunakan Uji F. Untuk melihat beda pengaruh antara perlakuan dilanjutkan dengan Uji BNJ pada taraf $5 \%$.

Langkah kerja yang ditempuh dalam penelitian ini adalah sebagai berikut:

1. Pembuatan pot (wadah) hidroponik sistem wick dengan botol mineral; Sediakan 1 botol mineral ukuran 1,5 liter, kemudian dipotong menjadi 2 bagian. Bagian bawah sebagai penampung nutrisi, dan bagian atas sebagai tempat media tanam. Bagian atas dilubangi (daerah leher botol) untuk pemasangan sumbu dan aliran udara. Masukkan bagian atas botol dimasukan dengan cara dibalik.

2. Pembuatan larutan nutrisi; Pembuatan larutan nutrisi dibuat sesuai dengan perlakuan yang telah ditentukan, setiap pot hidroponik diberi 500 ml/perlakuan dan diganti setiap 1 minggu sekali.

3. Penyiapan media tanam; Setelah pot dibuat masukkan media tanam yaitu sekam bakar, fungsi media ini hanya untuk pijakan akar agar tidak rebah.

4. Penanaman; Benih ditanam langsung di media yang telah disiapkan. Setiap wadah disemai 5 benih. Setelah bibit berumur 2 minggu dan berdaun 3 helai dilakukan penjarangan dengan hanya meninggalkan 1 bibit yang sehat.

5. Pemeliharaan; Pemeliharaan pada sistem hidroponik pada dasarnya tidak berbeda jauh dengan perawatan pada penanaman sistem konvensional seperti pembersihan gulma, dan pengendalian hama dan penyakit.

6. Panen; Panen dilakukan saat tanaman berumur 6 minggu setelah tanam (mst). Panen dilakukan dengan cara mencabut seluruh bagian tanaman secara hati-hati. Kemudian tanaman dibersihkan dari kotoran yang menempel setelah itu tanaman ditimbang.

7. Pengamatan; Dilakukan setiap minggu, dimulai dari 2 mst sampai dengan 6 mst, kecuali bobot basah dan bobot konsumsi diamati hanya saat panen. Parameter yang diamati adalah tinggi tanaman, jumlah daun, panjang daun, lebar daun, bobot basah dan bobot konsumsi.

\section{HASIL DAN PEMBAHASAN Tinggi Tanaman}

Hasil rekapitulasi analisis ragam menunjukkan pemberian berbagai dosis pupuk organik cair urin kelinci memberikan pengaruh nyata terhadap tinggi tanaman pada umur 4 mst yaitu $12,83 \mathrm{~cm}$, tetapi tidak berpengaruh nyata terhadap tinggi tanaman pada umur 2, 3, 5, dan 6 mst.

Hasil uji Beda Nyata Jujur (BNJ) pada taraf $5 \%$, rata-rata tinggi tanaman pakcoy pada minggu ke 4 mst menunjukkan perlakuan P4 memiliki tinggi tanaman tertinggi 12,83 cm namun tidak berbeda nyata dengan perlakuan P2, P3, dan P5 tetapi berbeda nyata dengan perlakuan P1 dengan tinggi tanaman terendah yaitu $11,10 \mathrm{~cm}$. 
Tabel 1. Pemberian Berbagai Dosis Urin Kelinci terhadap Rata-rata Tinggi Tanaman Pakcoy pada Umur 2-6 mst

\begin{tabular}{cccccc}
\hline \multirow{2}{*}{ Perlakuan } & \multicolumn{5}{c}{ Tinggi Tanaman $(\mathrm{cm})$} \\
\cline { 2 - 6 } & 2 MST & 3 MST & 4 MST & 5 MST & 6 MST \\
\hline P1 & 4,64 & 7,04 & $11,10 \mathrm{a}$ & 15,72 & 18,73 \\
P2 & 4,81 & 7,61 & $12,11 \mathrm{ab}$ & 16,76 & 19,89 \\
P3 & 4,67 & 7,48 & $11,75 \mathrm{ab}$ & 16,40 & 19,03 \\
P4 & 5,20 & 8,03 & $12,83 \mathrm{~b}$ & 16,97 & 20,58 \\
P5 & 4,85 & 7,67 & $12,03 \mathrm{ab}$ & 16,66 & 19,36 \\
\hline
\end{tabular}

Keterangan: Angka-angka yang diikuti huruf yang sama pada kolom yang sama tidak berbeda nyata berdasarkan uji BNJ pada taraf 5\%. P1 = $3 \mathrm{ml} / /, \mathrm{P} 2=6 \mathrm{ml} / /, \mathrm{P} 3=9 \mathrm{ml} / \mathrm{l}, \mathrm{P} 4=12 \mathrm{ml} / \mathrm{l}, \mathrm{P} 5=15 \mathrm{ml} / \mathrm{l}$.

Pada minggu ke 6 mst, perlakuan P4 memperlihatkan tinggi tanaman tertinggi yaitu 20,58 $\mathrm{cm}$, tidak berbeda nyata dengan semua perlakuan. Perlakuan P1 menunjukkan perlakuan tinggi tanaman terendah yaitu $18,73 \mathrm{~cm}$.

Pemberian pupuk organik cair urin kelinci $12 \mathrm{ml} / /$ dapat memacu pertumbuhan tanaman paling optimal dibandingkan dengan perlakuan lain. Hal ini diduga, karena pemberian unsur nitrogen (N) yang diserap oleh akar digunakan untuk pertumbuhan secara keseluruhan, terutama pada batang, cabang, dan daun (Lingga \& Marsono, 2001).

Pertumbuhan tinggi tanaman pakcoy berlangsung pada fase pertumbuhan vegetatif. Fase pertumbuhan vegetatif tanaman berhubungan dengan tiga proses penting yaitu pembelahan sel, pemanjangan sel, dan tahap pertama dari diferensiasi sel. Ketiga proses tersebut membutuhkan karbohidrat, karena karbohidrat yang terbentuk akan bersenyawa dengan persenyawaanpersenyawaan nitrogen untuk membentuk protoplasma pada titik-titik tumbuh yang akan mempengaruhi pertambahan tinggi tanaman. Ketersediaan karbohidrat yang dibentuk dalam tanaman dipengaruhi oleh ketersediaan hara bagi tanaman tersebut (Harlina, 2003).

Pada perlakuan P1 (3 m//l) tanaman pakcoy menunjukkan nilai yang terendah pada tinggi tanaman pada setiap pengamatan. Hal ini disebabkan oleh rendahnya unsur nitrogen dalam pupuk organik cair urin kelinci $3 \mathrm{ml} / \mathrm{l}$ sehingga menurunkan jumlah klorofil akibatnya laju fotosintesis berkurang dan pada akhirnya akan menghambat pertumbuhan tanaman karena terbatasnya produksi protein dan bahan-bahan penting pembentukan sel-sel baru (Eka, 2013).

\section{Jumlah Daun}

Berdasarkan rekapitulasi analisis ragam menunjukkan pemberian berbagai dosis pupuk organik cair urin kelinci memberikan pengaruh nyata terhadap jumlah daun pada umur 4 mst yaitu 5,90 helai dan tidak berpengaruh nyata terhadap jumlah daun pada umur 2, 3, 5, dan 6 mst.

Tabel 2. Pemberian Berbagai Dosis Urin Kelinci terhadap Rata-rata Jumlah Daun Pakcoy pada Umur 2-6 mst

\begin{tabular}{cccccc}
\hline \multirow{2}{*}{ Perlakuan } & \multicolumn{5}{c}{ Jumlah Daun (helai) } \\
\cline { 2 - 6 } & 2 MST & 3 MST & 4 MST & 5 MST & 6 MST \\
\hline P1 & 3,05 & 3,60 & $4,90 \mathrm{a}$ & 6,25 & 7,70 \\
P2 & 3,05 & 3,80 & $5,35 \mathrm{ab}$ & 7,00 & 8,80 \\
P3 & 3,05 & 3,70 & $5,05 \mathrm{ab}$ & 6,60 & 8,20 \\
P4 & 3,25 & 4,00 & $5,90 \mathrm{~b}$ & 7,20 & 9,10 \\
P5 & 3,10 & 3,90 & $5,20 \mathrm{ab}$ & 6,85 & 8,50 \\
\hline
\end{tabular}


Keterangan: Angka-angka yang diikuti huruf yang sama pada kolom yang sama tidak berbeda nyata berdasarkan uji BNJ pada taraf $5 \%$. P1= $3 \mathrm{ml} / /, \mathrm{P} 2=6 \mathrm{ml} / \mathrm{l}, \mathrm{P} 3=9 \mathrm{ml} / \mathrm{l}, \mathrm{P} 4=12 \mathrm{ml} / \mathrm{l}, \mathrm{P} 5=15 \mathrm{ml} / \mathrm{l}$.

Berdasarkan uji Beda Nyata Jujur (BNJ) pada taraf $5 \%$, rata-rata jumlah daun pakcoy pada minggu ke 4 mst menunjukkan perlakuan P4 memiliki jumlah daun tertinggi yaitu 5,90 helai namun tidak berbeda nyata dengan perlakuan P2, P3, dan P5 tetapi berbeda nyata dengan perlakuan P1 dengan jumlah daun terendah yaitu 4,90 helai.

Pada minggu ke 6 mst, perlakuan P4 memperlihatkan jumlah daun tertinggi yaitu 9.10 helai, tidak berbeda nyata dengan semua perlakuan. Perlakuan P1 menunjukkan perlakuan jumlah daun terendah yaitu 7,70 helai.

Meningkatnya jumlah daun berkaitan dengan tinggi tanaman. Semakin tingginya tanaman semakin banyak ruas batang yang akan menjadi tempat keluarnya daun. Menurut Gardner, Pearce, dan Mitchel (1991) bahwa batang tersusun dari ruas yang merentang di antara buku-buku batang tempat melekatnya daun, jumlah buku, dan ruas sama dengan jumlah daun.

Perlakuan P4 (12 ml/l) menunjukkan hasil tertinggi pada jumlah daun. Melihat kandungan hara yang terdapat pada urin kelinci antara lain kandungan N 2,72\%, kandungan $P$ 1,1\%, kandungan $\mathrm{K} 0,5 \%$, dan kandungan $\mathrm{H}_{2} \mathrm{O} 55,3 \%$ dimana kandungan $\mathrm{N}$ dari pupuk kelinci ini lebih tinggi dibandingkan dengan kotoran hewan lainnya (Anonim, 2010).

Lebih lanjut Rinsema dalam Wahyudiin (2004) bahwa unsur hara terutama nitrogen sangat berperan dalam pertumbuhan vegetatif tanaman, kadar nitrogen yang diserap akar tanaman sebagian besar akan naik ke daun bergabung dengan karbohidrat membentuk protein untuk pembentukan daun. Besarnya unsur hara yang diserap oleh akar akan mempengaruhi jumlah bahan organik dan jumlah mineral yang akan ditranslokasikan, diantaranya untuk pembentukan daun yang akhirnya akan meningkatkan jumlah daun.

\section{Panjang Daun}

Rekapitulasi analisis ragam menunjukkan pemberian berbagai dosis pupuk organik cair urin kelinci memberikan pengaruh nyata terhadap panjang daun pada umur 4 mst yaitu $11,60 \mathrm{~cm}$ dan tidak berpengaruh nyata terhadap panjang daun pada umur 2, 3, 5, dan 6 mst.

Tabel 3. Pemberian Berbagai Dosis Urin Kelinci terhadap Rata-rata Panjang Daun Pakcoy pada Umur 2-6 MST

\begin{tabular}{cccccc}
\hline \multirow{2}{*}{ Perlakuan } & \multicolumn{5}{c}{ Panjang Daun $(\mathrm{cm})$} \\
\cline { 2 - 6 } & 2 MST & 3 MST & 4 MST & 5 MST & 6 MST \\
\hline P1 & 3,60 & 5,96 & $9,75 \mathrm{a}$ & 12,44 & 16,16 \\
P2 & 3,85 & 6,60 & $10,70 \mathrm{ab}$ & 13,45 & 16,91 \\
P3 & 3,62 & 6,43 & $10,49 \mathrm{ab}$ & 13,26 & 16,33 \\
P4 & 3,96 & 7,01 & $11,60 \mathrm{~b}$ & 14,23 & 17,59 \\
P5 & 3,82 & 6,55 & $10,65 \mathrm{ab}$ & 13,34 & 16,42 \\
\hline
\end{tabular}

Keterangan: Angka-angka yang diikuti huruf yang sama pada kolom yang sama tidak berbeda nyata berdasarkan uji BNJ pada taraf $5 \% . P 1=3 \mathrm{ml} / /, \mathrm{P} 2=6 \mathrm{ml} / \mathrm{l}, \mathrm{P} 3=9 \mathrm{ml} / \mathrm{l}, \mathrm{P} 4=12 \mathrm{ml} / \mathrm{l}, \mathrm{P} 5=15 \mathrm{ml} / \mathrm{l}$.

Hasil uji Beda Nyata Jujur (BNJ) pada taraf 5\%, rata-rata panjang daun pakcoy pada minggu ke 4 mst menunjukkan perlakuan P4 memiliki rata-rata panjang daun terpanjang yaitu $11,60 \mathrm{~cm}$ namun tidak berbeda nyata dengan perlakuan $\mathrm{P} 2$, P3, dan P5 tetapi berbeda nyata dengan perlakuan $\mathrm{P} 1$ dengan panjang daun terpendek yaitu $9,75 \mathrm{~cm}$. 
Pada minggu ke 6 mst, perlakuan P4 memperlihatkan panjang daun terlebar 17,59 cm tetapi tidak berbeda nyata dengan semua perlakuan. Perlakuan P1 menunjukkan perlakuan panjang daun terpendek yaitu $16,16 \mathrm{~cm}$.

Panjang daun terpanjang terdapat pada perlakuan P4 (12 ml), hal ini diduga karena panjang daun berhubungan dengan tinggi tanaman serta jumlah daun, semakin tinggi tanaman dan jumlah daun, semakin panjang juga daun yang dihasilkan. Sementara itu Teuku, Asril, dan Syukri (2013), bahwa pemberian urin kelinci terdapat peningkatkan jumlah daun dan tinggi tanaman sehingga meningkatkan jumlah biomassa pada tanaman dan mampu meningkatkan bobot segar tanaman.

\section{Lebar Daun}

Hasil rekapitulasi analisis ragam menunjukkan pemberian berbagai dosis pupuk organik cair urin kelinci memberikan pengaruh nyata terhadap lebar daun pada umur 4 mst dan tidak berpengaruh nyata terhadap jumlah daun pada umur 2, 3, 5, dan 6 mst.

Tabel 4. Pemberian Berbagai Dosis Urin Kelinci terhadap Rata-rata Lebar Daun Pakcoy pada Umur 2-6 mst

\begin{tabular}{cccccc}
\hline \multirow{2}{*}{ Perlakuan } & \multicolumn{5}{c}{ Lebar Daun (helai) } \\
\cline { 2 - 6 } & 2 MST & 3 MST & 4 MST & 5 MST & 6 MST \\
\hline P1 & 1,27 & 2,05 & $4,11 \mathrm{a}$ & 5,11 & 6,17 \\
P2 & 1,51 & 2,16 & $4,65 \mathrm{ab}$ & 5,87 & 6,95 \\
P3 & 1,39 & 2,10 & $4,49 \mathrm{ab}$ & 5,36 & 6,56 \\
P4 & 1,60 & 2,43 & $5,13^{\mathrm{b}}$ & 6,27 & 7,36 \\
P5 & 1,47 & 2,11 & $4,54 \mathrm{ab}$ & 5,59 & 6,81 \\
\hline
\end{tabular}

Keterangan: Angka-angka yang diikuti huruf yang sama pada kolom yang sama tidak berbeda nyata berdasarkan uji BN J pada taraf 5\%. P1= $3 \mathrm{ml} / /, \mathrm{P} 2=6 \mathrm{ml} / \mathrm{l}, \mathrm{P} 3=9 \mathrm{ml} / \mathrm{l}, \mathrm{P} 4=12 \mathrm{ml} / \mathrm{l}, \mathrm{P} 5=15 \mathrm{ml} / \mathrm{l}$.

Nilai uji Beda Nyata Jujur (BNJ) pada taraf 5\%, rata-rata lebar daun pakcoy pada minggu ke 4 mst menunjukkan perlakuan P4 memiliki rata-rata lebar daun terlebar yaitu 5,13 cm namun tidak berbeda nyata dengan perlakuan P2, P3, dan P5 tetapi berbeda nyata dengan perlakuan P1 dengan lebar daun tersempit yaitu $4,11 \mathrm{~cm}$.

Pada minggu ke 6 mst, perlakuan P4 memperlihatkan lebar daun terpanjangyaitu $7,36 \mathrm{~cm}$ tetapi tidak berbeda nyata dengan semua perlakuan. Perlakuan P1 menunjukkan perlakuan lebar daun tersempit yaitu $6,17 \mathrm{~cm}$.

Perlakuan P4 menunjukkan lebar daun tanaman pakcoy terlebar setiap pengamatan. Hal ini diduga karena ketersediaan unsur hara yang cukup untuk pertumbuhan tanaman akan mendukung laju fotosintesis yang cepat dan sempurna, maka pada proses pembentukan karbohidrat, lemak, dan protein dapat berjalan dengan sempurna pula, sehingga akan diperoleh hasil yang maksimal (Krisna, 2014). Keadaan didukung oleh pendapat Gardner, Pearce, dan Mitchell (1991) yang menyatakan efesiensi fotosintesis terjadi bila luas daun lebih lebar, sehingga produk fotosintat menjadi lebih optimal. Lakitan (2012), menambahkan jika kandungan hara cukup tersedia maka luas daun suatu tanaman akan semakin tinggi, dimana sebagian besar asimilat dialokasikan untuk pembentukan daun yang mengakibatkan luas daun bertambah. 


\section{Bobot Basah dan Bobot Konsumsi}

Hasil rekapitulasi menunjukkan pemberian analaisis ragam berbagai dosis pupuk organik cair urin kelinci memberikan pengaruh tidak nyata terhadapnyata terhadap bobot basah dan bobot konsumsi pada semua perlakuan.

Tabel 5. Pemberian Berbagai Dosis Urin Kelinci terhadap Rata-rata Bobot Basah dan Bobot Konsumsi Pakcoy pada Umur 6 MST

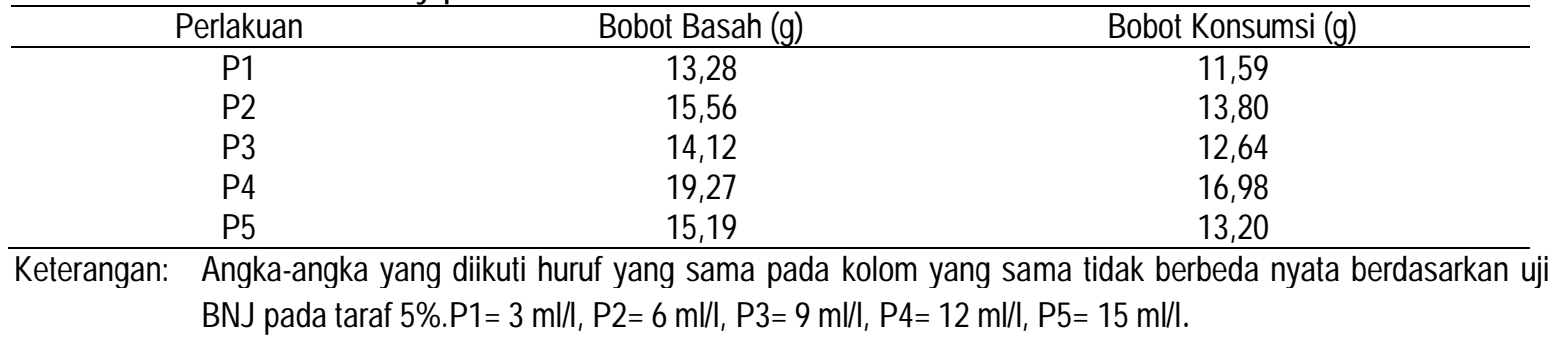

Berdasarkan uji Beda Nyata Jujur (BNJ) pada taraf 5\%, rata-rata bobot basah tanaman pakcoy pada umur 6 mst menunjukkan perlakuan P4 memiliki rata-rata bobot basah tertinggi yaitu $19.27 \mathrm{~g}$ namun tidak berbeda nyata dengan semua perlakuan dan perlakuan dengan bobot basah terendah terdapat pada perlakuan P1 yaitu $13,28 \mathrm{~g}$.

Tabel 5 menunjukkan rata-rata bobot konsumsi tanaman pakcoy pada umur 6 mst untuk perlakuan P4 memiliki rata-rata bobot konsumsi terberat yaitu 16,98 $\mathrm{g}$ tetapi tidak berbeda nyata dengan semua perlakuan dan perlakuan dengan bobot konsumsi terendah terdapat pada perlakuan P1 yaitu $11,59 \mathrm{~g}$.

Respon tanaman pakcoy terhadap pemberian berbagai dosis pupuk organik cair urin kelinci pada umur 6 mst memberikan hasil tertinggi yaitu 19,27 g dan 16,98 g tetapi tidak berbeda nyata dengan perlakuan dosis yang lainnya. Hasil produksi yang dihasilkan ini masih di bawah rata-rata, pada lingkungan yang mendukung hasil produksi tanaman pakcoy dapat mencapai hasil rata-rata 80,4-118,8 g/tanaman.

Temperatur yang tinggi pada saat penelitian berlangsung mempengaruhi fisiologi tanaman karena secara langsung akan mempengaruhi proses fotosintesis, respirasi, penyerapan air dan unsur hara serta translokasi yang akhirnya mempengaruhi pertumbuhan tanaman pakcoy. Salisbury dan Ross (1995), menyatakan bahwa pertumbuhan tanaman sangat dipengaruhi oleh suhu, perubahan suhu berapa derajat saja dapat menyebabkan perubahan yang nyata terhadap laju pertumbuhan suatu tanaman. Temperatur yang terlalu tinggi dapat menyebabkan kelembaban udara rendah dan akan mengakibatkan kekeringan. Selain itu menurut Jumin (2004) menyatakan suhu akan mempengaruhi proses fisiologis tanaman dalam hal pertumbuhan tanaman jika suhu tinggi dan kelembaban rendah menyebabkan terhambatnya penyerapan unsur hara karena transpirasi meningkat dan proses fotosintesis terhambat.

Hasil pengamatan yang mencakup tinggi tanaman, jumlah daun, panjang daun, lebar daun, bobot basah dan bobot konsumsi tanaman pakcoy menunjukkan bahwa perlakuan P4 (12 ml/l) mempunyai hasil yang lebih tinggi dibandingkan dengan perlakuan lainnya. Hal ini diduga bahwa dosis tersebut merupakan dosis yang dibutuhkan tanaman pakcoy dengan sistem hidroponik wick. Pendapat ini sejalan dengan penelitian Palimbungan, Labatar dan Hamzah (2006), bahwa pemberian pupuk cair dalam jumlah yang sesuai dengan kebutuhan tanaman mendukung terjadinya pertumbuhan tanaman optimal yang menyebabkan proses pembelahan, pembesaran, dan 
pemanjangan sel akan berlangsung dengan cepat yang mengakibatkan beberapa organ tanaman tumbuh dengan cepat.

Respon tanaman pakcoy terhadap dosis pupuk organik cair urin kelinci pada dosis yang lebih tinggi yaitu perlakuan P5 (15 ml/l air) menyebabkan tinggi tanaman, jumlah daun, panjang daun, lebar daun, bobot basah, dan bobot konsumsi tanaman pakcoy menurun. Hal ini diduga karena tanaman pakcoy dengan sistem hidroponik telah mengalami kejenuhan hara sehingga daun tanaman pakcoy tidak mampu menyerap hara secara optimal. Pendapat ini sesuai dengan Zainuddin (2012), bahwa pemberian pupuk organik cair kotoran sapi $15 \mathrm{ml} / \mathrm{l}$ menyebabkan penurunan tinggi tanaman, jumlah daun, luas daun, bobot basah, dan konsumsi tanaman sawi.

Menurut Indrakusuma (2000), penurunan tinggi tanaman, jumlah daun, panjang daun, lebar daun, bobot basah dan bobot konsumsi tanaman disebabkan penambahan pupuk organik cair menyebabkan bertambahnya hara yang tersedia dalam media dan daun sehingga terjadi kelebihan hara yang diserap tanaman.

Hal ini akan mengganggu keseimbangan hara yang diserap, sehingga akan menekan pertumbuhan tanaman. Pada perlakuan P1 (3 ml/l) tanaman pakcoy menunjukkan nilai yang terendah untuk semua peubah. Hal ini disebabkan karena kandungan unsur hara yang rendah dalam pupuk organik cair urin kelinci sehingga tidak mampu untuk mencukupi kebutuhan unsur hara yang dibutuhkan oleh tanaman pakcoy untuk pertumbuhan dan perkembangannya. Hardjowigeno (2003) mengemukakan bahwa salah satu kelemahan pupuk organik adalah kandungan hara yang rendah serta pengaruh terhadap tanaman sangat lamban.

\section{KESIMPULAN}

Perlakuan dosis pupuk cair urin kelinci $12 \mathrm{ml} / /$ memberikan pengaruh tertinggi pada peubah tinggi tanaman, jumlah daun, panjang daun, lebar daun, bobot basah dan bobot konsumsi, sedangkan dosis pupuk organik cair urin kelinci $3 \mathrm{ml} / \mathrm{l}$ memberikan hasil yang terendah. Walaupun secara uji statistik tidak berbeda nyata hasil antara perlakuan $\mathrm{P} 1=3 \mathrm{ml} / \mathrm{l}, \mathrm{P} 2=6 \mathrm{ml} / \mathrm{l}, \mathrm{P} 3=9 \mathrm{ml} / \mathrm{l}, \mathrm{P} 4$ $=12 \mathrm{ml} / \mathrm{l}$, dan P5 = $15 \mathrm{ml} / \mathrm{l}$.

\section{REFERENSI}

Afrizal. (2012). Cara Hidroponik. Diambil tanggal 25 Maret 2014 dari: http://carahidroponik.blogspot.com/search /label/Cara\% 20Bertanam\%20Hidroponik.

Anonim. (2010). POC. Diambil tanggal 25 Maret 2014 dari: http://warungtanimandiri.blogspot.com/2010/01/poc-warung-tani-mandiri 23.html.

Basuki, T.A. (2008). Pengaruh macam komposisi hidroponik terhadap pertumbuhan hasil selada (Lactuca sativa L.). Skripsi. Yogyakarta: Fakultas Pertanian UGM.

Eka. (2013). Pengaruh pemberian pupuk cair hasil fermentasi kotoran padat kelinci terhadap pertumbuham sambiloto (Andrographis paniculata Ness.) Sebagai Sumber Belajar Biologi SMA Kelas XII. JUPEMASI-PBIO Vol 1. Yogyakarta.

Gardner FB, Pearce RB, \& Mitchell RL. (1991). Phsycology of crop anatomi. Diterjemahkan oleh H. Susilo. Jakarta: Universitas Indonesia Press.

Hardjowigeno, S. (2003). Ilmu tanah. Jakarta: Penerbit Akademika Pressindo.

Harlina N. 2003. Pemanfaatan pupuk majemuk sebagai sumber harabudidaya terung secara hidroponik. Skripsi. Bogor: Fakultas Pertanian IPB.

Haryanto, Suhartini, Rahayu, dan Sunarjo. (2007). Sawi dan Selada. Jakarta: Penebar Swadaya. 
Indrakusuma. (2000). Proposal pupuk organik cair supra alam lestari. Yogyakarta: Surya Pratama Alam..

Jumin, H. D. (2004). Dasar-Dasar Agronomi. Jakarta: Rajawali Press..

Krisna. (2014). Respon pertumbuhan dan hasil tanaman jagung (Zea Mays L.) terhadap pemberian pupuk organik cair ampas nilam. JOURNAL UNITAS. Padang.

Lingga P. \& Marsono. (2001). Petunjuk penggunaan pupuk. Jakarta: Penebar Swadaya.

Lakitan. (2012). Dasar-dasar fisiologi tumbuhan. Jakarta: Raja Grafindo Persada..

Mappanganro N., Sengin E.L., Baharuddin. (2012). Pertumbuhan dan produksi tanaman stoberi pada berbagai jenis dan konsentrasi pupuk organik cair dan urin sapi dengan sistem hidroponik tetes. Makasar: Fakultas Pertanian Universitas Hasanudin.

Paiman \& Erika D. N. (2010). Pengaruh konsentrasi dan frekuensi pemberian pupuk urin kelinci terhadap pertumbuhan dan hasil tomat. Yogyakarta: Fakultas Pertanian Universitas PGRI Yogyakarta.

Palimbungan N., R. Labatar, \& F. Hamzah F. (2006). Pengaruh ekstrak daun lamtoro sebagai pupuk organik cair terhadap pertumbuhan dan produksi tanaman sawi. Jurnal Agrisitem 2. Gowa.

Salisbury, F.B. dan Ross, C.W. (1995). Fisiologi tumbuhan, Jilid 3. Terjemahan Diah R. Lukman dan Sumaryono. Bandung: ITB.

Teuku A.D., Asril B., \& Syukuri. (2013). Respon pertumbuhan dan produksi sawi (brassicajuncea I.) terhadap pemberian urine kelinci dan pupuk guano. Jurnal Online Agroteknologi Vol. 1. Medan.

Wahyudiin, D. (2004). Pengaruh takaran urea dan pupuk daun multitonik terhadap pertumbuhan dan hasin caisin kultivar green pakcoy. Jurusan Budidaya Pertanian Fakultas Pertanian Universitas Siliwangi. Tasikmalaya.

Zainuddin. (2012). Pengaruh dosis pupuk organik cair (poc) kotoran sapi terhadap pertumbuhan dan produksi tanaman sawi hijau (brassica sinensis L.). Jurnal Agroforestri. Sorong.

Zulkarnain, H. (2010). Dasar-dasar hortikultura. Jakarta: Bumi Aksara. 